\title{
Empirical Study on Impact of Integrated watershed Development project in Mizoram state of north east india
}

\author{
Dr. A. Sundaram, \\ Associate Professor, Dept. of Economics, Govt Saiha College, Affiliated to Mizoram University, Saiha, \\ Mizoram, North East India-796901
}

\begin{abstract}
The present study was conducted with an objective to assess impact of integrated watershed development programme in Mizoram State of North East India. The study is based on primary and secondary data. Primary data was collected from a random sample of the beneficiary households selected in the watershed area. The sample size was 105 households of the 7 project villages. Equal numbers of households were selected from each watershed village on the basis of systematic random sampling. The survey was conducted during November 2010. This study employed both qualitative and quantitative methods approach for evaluating watershed projects. Author surveyed 7 watershed villages in Mizoram and collected socio-economic data from the watershed officials and primary stakeholders. Jhum cultivation causes serious land degradation and ecological problems in Mizoram. Integrated Wasteland Development Programme (IWDP) is carried out on watershed approach with a theme of land and water resource management. This study has examined its effect on sustainable development of natural resources, environment protection, and improvement of the socioeconomic conditions of the resource poor sections on participatory approach. Generally people in the watershed area are generously appreciated the watershed project because when we compare with other centrally sponsored schemes it is the only scheme reaching to the common poor people's door. They felt that if this scheme is implemented in a systematic and effective manner it will benefit the common people immensely and more productively. The project potential is very high. In order to realize this potential, it needs transparency and efficiency in implementation.
\end{abstract}

Keywords: ecological, environment, destruction, degradation, jhum cultivation, poor socio-eocnomic condition.

\section{Introduction}

Initially, Jhumming worked well, as Jhum cycle was ranging from 20 to 30 years, but with increase in human population and increased demands on lands, this Jhum cycle has got reduced to 2-5 years. Jhum cultivation causes serious land degradation and ecological problems in Mizoram. Indiscriminate destruction of forests, as a result of shifting cultivation, coupled with high rainfall lead to various problems such as ecological imbalance, acceleration of soil erosion, loss of nutrients etc.

The Planning Commission approved implementation of Scheme of Watershed Development Project in Shifting Cultivation Areas (WDPSCA) in N.E. Integrated Wasteland Development Programme (IWDP) is carried out on watershed approach with a theme of land and water resource management for sustainable development of natural resources, environment protection, and improvement of the socio-economic conditions of the resource poor sections on participatory approach.

The Department of Land Resources, Govt. of India, has sanctioned 17 (seventeen) Projects under 'Revised Guidelines, 2001' and 35 (thirty five) Projects under 'Hariyali Guidelines, 2003' for Mizoram. The total projected area to be covered is 4, 33,803 hectares and the approved financial involvement is Rs. 26,028.88 lakhs. The funding pattern between the Central and State Governments is on 90:10 ratios respectively. The targeted period for completion of such projects is 5 (five) years. The fund released by Government of India is in 7 (seven) instalments in case of IWDP and 5 (five) instalments in Hariyali.

The National Remote Sensing Agency in its Publication 'Wastelands Atlas of India' 2005, has indicated that $21.20 \%$ of the total geographical area of 21,081 Sq.Km, in Mizoram as wasteland of different categories. This translates into 4469.88 Sq.Km as total wasteland in Mizoram. Shifting Cultivation (current) forms the main chunk of such wasteland and next comes the abandoned Jhum land.

\section{Objectives Of The Study:}

1.1. To find out how far this project has promoted the economic development of the village community which is directly or indirectly dependent on the watershed?

1.2. To find out the Optimum utilization of the watershed's natural resources like land, water, vegetation, etc. that has mitigated the adverse effects of drought and prevent further ecological degradation. 
1.3. To find out the Employment generation and development of the human and other economic resources of the village in order to promote savings and other income-generation activities.

1.4. To find out the restoration of ecological balance in the village.

1.5. To find out the Sustained community action for the operation and maintenance of assets created and further development of the potential of the natural resources in the watershed. Simple, easy and affordable technological solutions and institutional arrangements that make use of and build upon, local technical knowledge and available materials.

1.6. Whether Special emphasis has given to improve the economic and social condition of the resources-poor and the disadvantaged sections of the Watershed Community such as the asset less and the women.

1.7. Whether this project has achieved equitable distribution of the benefits of land and water resources development and the consequent bio-mass production. Greater access to income generating opportunities and focus on their human resource development.

1.8. Adequacy of the efforts made to maintain the infrastructure developed under the scheme.

1.9. To evaluate the impact of the scheme.

1.10. To suggest measures.

\section{Methodology}

Quantitative and qualitative evaluation methods, which traditionally have been used separately, both have strengths and weaknesses. Combining them can make evaluation more effective, particularly when constraints to study design exist.

This study employed mixed-methods approaches for evaluating watershed projects. Author surveyed 7 watersheds villages in Mizoram and collected socio-economic data from the watershed officials and primary stakeholders. The study is based on primary and secondary data. Primary data was collected from a random sample of the beneficiary households selected in the watershed area. The sample size was 105 households of the 7 project villages. Equal numbers of households were selected from each watershed village on the basis of systematic random sampling. The survey was conducted during November 2010. The tool kit consists of household survey, village survey, group discussions, and discussions with leaders, NGOs, SHGs and Govt officials. In the village survey, participatory rural appraisal techniques, village profile, and informal group discussions were employed. For obtaining household survey, pre-tested questionnaires, semi-structured questionnaires, and informal interviews with interview guide were the main tools used.

In order to evaluate the performance of the IWDP project in this study, different frameworks were employed to analyse the information.

\section{Limitations:}

Insufficient and improper availability of data was prevailing. The respondents are not revealing the facts sometimes due to many drawbacks. There was no proper and sufficient record availability in the watershed area. Some watershed projects may have short term effects and may have long term impacts, some of which may be difficult to evaluate or even perceive.

\section{V. $\quad$ Findings On Impact Of Integrated Watershed Development Programme In Mizoram}

Generally people in the watershed area are generously appreciated the watershed project because when we compare with other centrally sponsored schemes it is the only scheme reaching to the common poor people's door. They felt that if this scheme is implemented in a systematic and effective manner it will benefit the common people immensely and more productively. The project potential is very high. In order to realize this potential, it needs transparency in implementation.

\subsection{Physical Capital:}

Watershed treatment such as bunding, land reclamation and the construction of farm ponds, fish ponds and other conservation structures have been carried out on private property resources And common property resources done moderately and not up to the allocation of fund.The project improved agricultural practices and bio-diversity by introducing sustainable agriculture practices not up to the capacity of the project.At the individual household level, assets for livelihood promotion were not created considerably for the poor and landless. Very few self-help groups are formed and their roles and responsibilities are not understood by them.

\subsection{Natural Capital:}

Impact on Natural capital asset was not as positive as expected. There was also marginal improvement in the terms of fodder availability of the sample villages studied. Another improvement is in the form of increased availability of drinking water. Being the natural resource based project, most of the project 
investments were enhancing the natural capital and reducing vulnerability of the poor and marginal sample farmers marginally. Resources were created in both (PPRs) Public Private Property and (CPRs) Common Property Resources like water point. The physical inputs have contributed towards the conservation and stabilization of the agro eco system. Project intervention allowed cultivable wasteland brought under cultivation to some extent. Through moisture conservation the ground water levels have raised improving access to drinking water for humans and animals. Home gardens were initiated by using tubes improved fodder varieties to small and marginal farmers for soil fertility and nutrition management.

\subsection{Human Capital:}

Impact on human capital asset was little and the expenditure on education was increased significantly. Capacity building was a major component for the project and it did not enhance that much of the knowledge, skills and attitudes of the project staff, community, resource persons and community members. Much training were not offered in the areas of watershed management institution building, agricultural production, livelihood promotion, labour management, community mobilization, book keeping and accounting, project management and planning etc. Young community resource persons from the village were not trained to provide services to the different community level institutions. Capacities in other development areas like health and education were also observed.

\subsection{Social Capital:}

Since the social development is a complex and long process, the study attempted to assess the social impact in terms of migration and gender. It was reported that migration of people was less during the implementation period of watershed which created additional employment in the villages. The other positive impact was strengthening the self help groups (SHG) through better employment. The project created socially inclusive institutions at the village and project levels with representation of all sections but not considerably. These institutions both formally and informally helped to organize communities and reduce the existing social discrimination to less extent. The enhanced social capital helps to solve common problems like building access roads etc to a certain extent. Village Watershed Committee, Team and Association were promoted but not with a vision as well as effectively to function beyond the project period for village level development works.

\subsection{Financial Capital:}

Impact on this capital asset was positive in terms increased land productivity, increased employment in villages and significant increase in household income as compared to the outside project area. This study provide enough but not sufficient evidence that participatory watershed management program met the desired objectives towards creating sustainable rural livelihoods in Mizoram. It has been observed that participatory watershed management projects was helpful in raising income, agricultural productivity, generating employment and conserving soil and water resources but not up to the potential of the project expectation. Little Evidence is found from the study that watershed development brought several positive trends including diversification of the rural economy, development of new institutions, increasing cropping intensity, improved fodder production, increased availability of drinking water with rising ground water table, capacity development of the community etc.

\subsection{Livelihood Outcome:}

Most of the activities have helped in improving agriculture, the mainstay of the rural livelihoods but also in empowering communities, especially the marginalized in social, financial and human development projects. Migration from project villages reduced as work was locally available during the lean season. Many households were able to repay their old debts.

\subsection{Community Management:}

The physical capital created in the villages led to an increase in natural resources (water, irrigated cultivated land, and pastureland), household incomes and food security. The project to be ended in 2010 but WC, SHG, and User groups' members were not so interested to continue to manage and maintain the assets in the same sprit as agreed during the project. The capacity of the community to collectively plan, negotiate and avail themselves of opportunities on their own would help increased capacity to cope with any adverse condition including climate related risks.

\subsection{Tank rehabilitation:}

Increased water storage capacity of tanks helped to capture rainwater run-off, thereby making water available longer periods but only a few water storage has been constructed. Formation of user group provision of revolving funds increased the income of the fishing communities to some extent. Given the crop- 
livestock-environment relationship, the up gradation of animals helps to secure and strengthen livestock based livelihoods conditions.

\section{Suggestions For Further Improvement In Sustainability Of Implementation Of IWDP Scheme In Mizoram:}

1.19. WC and beneficiaries suggested that publicity and awareness campaigning about the project and its objectives is a must before implementing the programme.

1.20. Most of the Chairman of WC emphasized that they should know their power and responsibilities to involve in watershed planning, implementation and maintenance of assets created. They should know that why watershed project to be implemented and what benefit they are going to acquire and to what extent and criteria of selection watershed families, kind of activities to be implemented etc.

1.21. Beneficiaries also suggested that WC members should be given importance in consulting on every matter related to the schemes and official notification should be done on everything and transparency should be maintained among the members of the watershed committee in consultation, decision making, implementation, and maintenance of assets etc.

1.22. WC and the beneficiaries suggested that training is to be imparted to volunteers including Panchayats members on essential aspects of planning, application of participatory tools and to work voluntarily.

1.23. WC has to meet on every aspect of the plan making, selection of families; the kind of activities to be implemented etc and watershed Committee should be established in every watershed villages. The existence of watershed Association, Watershed Team and its functions to be announced or intimated to the WC and people.

1.24. All the beneficiaries are selected with the prior consultation and knowledge of the WC chairman and its members.

1.25. The proposal sent by the WC should be followed in selecting the beneficiaries and if any with the consultation WC and its members.

1.26. Provision should be given considerably to participate women and from weaker sections so the exercise is more socially inclusive.

1.27. While selection of beneficiaries the poor and landless farmers to be given much importance whereas the selection should not be based on the influence of the political will and richness of the family background. Besides, the selection should be based on the requirement and the demand of the local community.

1.28. The project implementation procedure has to be a top-down approach but it should not be violated in many aspects. Mainly they should take into account the plans and aspirations of WC and the people at the grass root level considerably.

1.29. The available fund should be utilized optimally or efficiently so that the fund flow is assured fully to the beneficiaries or watershed area.

1.30. Professionals should help in preparation of planning and effective leadership to most of the local bodies of this district.

1.31. The resource envelope must be shared with the local bodies so that that they can prepare good and realistic plan for their areas.

1.32. The monitoring and evaluation mechanism related to decentralize planning should be strong and effective oriented. More importance to be given to monitor the process and outcome of planning

1.33. All the records and accounts should be kept with the WC.They should be given training on how to prepare and maintain records and account related to the watershed project. They should be cultivated all the requisite knowledge about the scheme availability, development, selection of beneficiaries, and the amount sanction etc.

1.34. Importance should be given proportionately to individual beneficiaries oriented as well as creation community assets and infrastructure.

1.35. Emphasis is to be given to plant more number of horticulture plants and creation of rain water harvesting.

1.36. Importance is to be given according to the need in establishing access road to reach the beneficiary place.

1.37. The approach to focus on development of land with village community as a whole and the practice of well organizing the community to achieve the goals of watershed is to be followed considerably.

1.38. Authorities should communicate on availability of fund under various programmes to the Grama Panchayats.

1.39. Integration should be maintained at Gramapanchayat level budget in respect of NREGS with other planned activities and taken up in a convergent mode between NREGS and other programmes.

1.40. Beneficiaries should receive all the sanctioned numbers of HYV saplings or seedlings in good quality and to be supplied on time.

1.41. Water storage Beneficiaries to be supplied the required iron pipes instead of rubber tubes. 
1.42. The amount of money sanctioned for terrace for one hectare should be at least Rs. 30000 and for fish pond at least Rs. 60000 so that they may be able to complete the work fully and derive the benefit.

1.43. The sustainability of agriculture is possible by harnessing rainwater and improving the groundwater and effective and appropriate soil and water conservation measures.

1.44. Sustained community action for the operation and maintenance of assets created and further development of the potential of the natural resources in the watershed is very important.

1.45. Social justice and poverty alleviation can be achieved by transparency in implementation.

1.46. It is suggested that future evaluation may benefit from focusing not simply tracking the expenditure enquiry but on the final outcome and on the process that lead to final outcomes.

1.47. Beneficiaries suggested that planting of trees and grass seeding can be taken up during the monsoons. Therefore the activities should be planned accordingly. To start a project during or just before the monsoon is not advantageous. It should be on the right time.

1.48. In addition to laying emphasis on physical measures equal or greater attention should be paid to agricultural programmes to help the farmers to take up improved farming practices and get maximum benefits from the infrastructure created under the project.

1.49. Training and Capacity Building of volunteers, WC members, SHGs, User Groups, and NGOs may be taken up on intensive scale and the Review and Monitoring system should be intensified.

1.50. There should also be enough trained manpower before the project starts. A core team of village youth would have to first undergo an orientation program to develop a clear idea of the project and the responsibilities of all persons involved with it. They would also need to acquire certain specific skills like surveying, staking, nursery raising, horticulture, pasture development, conservation measures, settled cultivation etc. for project preparation, implementation and maintenance.

1.51. Women should be actively involved in all aspects of project implementation as they not only do the bulk of farm related work but are also the transmitters of culture and values to children.

1.52. Most farmers suggested that improved, certified and guaranteed seeds in addition to enlarging water potential for sustainable agriculture and providing remunerative prices/market would usher agriculture growth in rained agro-eco regions.

1.53. In case of problems of any technology in watershed area this is to be entrusted with Research Institutes for improvement so as to create a confidence among the farmers towards sustainable growth of agriculture in Rainfed agro-eco regions.

1.54. Standard survey techniques to be employed for evaluation on the basis of 'Before' and 'After'/ 'Now' in case of bio-physical factors and 'with' and 'without' procedure through group discussion with farmers and project implementing agencies (PIAs) at each location. In case of socio-economic factors, 'with' (watershed villages) and 'without' (non-watershed villages) procedure to be followed.

1.55. Gradually, the watershed project management should be given to reside in the community. Various aspects of watershed development and management could be handed over to community organizations over time when they have been adequately trained. This will sustain development.

1.56. There is a need to assure the essential elements and mechanisms of village community participation in the development and management of natural resources.

1.57. Further research is needed to strengthen village-level institutions for watershed development and management.

1.58. Capacity building is a continuous process. The implementing agencies and staff of other organizations involved in the collaborative projects on watershed management need to be trained in the application of new scientific tools such as remote sensing, Geographic Information System (GIS) and systems modeling.

1.59. Socioeconomic and policy issues to promote the equitable sharing of costs and benefits of improved natural resources management need to be researched.

1.60. Procurement of Digital Satellite data for pre and post treatment periods to be taken into consideration.

1.61. There is a need to investigate and explore a range of opportunities through on-farm and off-farm activities to encourage and promote village level microenterprises, such as giving value addition to agricultural produce to help the landless, educated youth and women to ensure a more equitable sharing of the benefits of watershed management projects.

1.62. Watershed management projects need to become holistic livelihood projects, with soil and water conservation activities used as entry points.

1.63. Systematic planning and mapping is required to prepare a plan to develop and maintain natural resources soil, water and vegetation for sustainable growth of agriculture in rained agro-eco regions in Saiha District. Capacity building is a prerequisite for effective implementation of WDPs.

1.64. Sustainable community-managed systems are needed and they can succeed only with farmer's contribution and their commitment of time and resources. Equitable distribution of water amongst the families has also been one of the main factors in the success. 
1.65. Watershed development programmes require a comprehensive integrated approach involving several line departments and the quality of project preparation and implementation. So a mechanism has to be found for sustainable development involving local interest groups who can be oriented to carry forth the basic lessons of the project period.

1.66. Sufficient number of water harvesting activities to be taken up.

1.67. Active participation of people/community in watershed development programme is very important in its success. The programme needs to be reoriented in favor of the people, their animals-cows, buffaloes, goats, etc., the forests, common lands, wastelands etc. for their improved productivity. The main purpose of the programme should be to promote the welfare of the poor and their ownership over the community and natural resources. The participation of women and landless in decision making is also important for their active involvement.

1.68. The beneficiaries suggest that the financial requirements for Watershed Development Programme should be worked out on per family basis rather than the current practice of working out the budget on per unit area (hectare) basis.

1.69. The main purpose of the programme should be to promote welfare of the poor and their ownership over community \& natural resources. Unless survival biomass needs of the rural poor are satisfied within the project area, the objective of the watershed development programme would not be achieved. One way is to allot specifically, funds for the families below the poverty line out of the total funds for livelihood security. They should also be encouraged to form into beneficiary groups, so that they have a say in project planning and implementation. The beneficiary groups should be comprised of families of similar interest and status.

1.70. The availability of sanctioned funds must be available at the right time to the Project Implementing Agencies (PIA). This procedure would ensure timely utilization and release of funds. If the sanctioned amount is not utilized within the stipulated time, it would forfeit its claim for central funds for the second quarter. There should be financial discipline.

1.71. The rural communities -landowners and land users should feel the innate urge and need for developing their own natural resources to secure short term, medium term and long term benefits. Thus a movement of self-initiative and self-reliance in respect of natural resources development and management should be created by all stakeholders.

1.72. More importance to be given to select more number of families and more number of the relevant items of activities according to the project criteria.

1.73. Most of the people suggested that every family should be allotted land at least a hectare as a permanent basis in all watershed villages so that they can avail the benefit of central sponsored programmes and increase the production, which inturn effect the livelihood of the people.

1.74. People also suggested that let the Govt of Mizoram make sure that every family is allotted land to the minimum level or according to the family numbers and the remaining land in the villages let it be declared as reserved or community or open forest. So that Mizoram's development will be faster and effective.

\section{Acknowledgement:}

I am submitting you my Research Paper titled "EMPIRICAL STUDY ON IMPACT OF INTEGRATED WATERSHED DEVELOPMENT PROJECT IN MIZORAM OF NORTH EAST INDIA" for your kind consideration and necessary action please. I am really indebted to you for taking necessary action regarding my research paper. Kindly acknowledge me. I express wholeheartedly my gratitude for your great service in disseminating this kind of knowledge through your valuable journals to the world.

\section{References:}

[1] Deshpande R. S and V. Ratna Reddy (1990), "Social Dynamics and Farmer's Society: A Case Study of Pani-Panchayat," Indian Journal of Agricultural Economics, Vol. 45,No. 3, July-September.

[2] Deshpande R.S. and, V. Ratna Reddy (1991). Differential impact of watershed based technology: Some analytical issues. Indian Journal of Agricultural Economics, 46(3):261-269.

[3] Fan S, and Hazell P. (2000). Should developing countries invest more in less favoured areas?An empirical analysis of rural India. Economic and political weekly, 35(17): 14551464.

[4] GoI (2001) Approach Paper to the Tenth Five Year Plan (2002-07), Planning Commission,New Delhi, September.

[5] GoI (2003) Watershed Guidelines (Hariyali), Ministry of Rural Development, New Delhi

[6] GoI (2006), From Haryali to Neeranchal: Report of the Technical committee on Watershed Programmes in India, Department of Land Resources, Ministry of Rural Development, Government of India, January.

[7] Joshi, P.K and Bantilan, M.C.S (1997): Vertisol Watershed research in the semi-arid tropics:Directions for impact Assessment', Artha Vijnana, Vol.39, No.3.

[8] Joshi,P.K.,Jha,A.K.,Wani,S.P.,Joshi,L., and Shiyani,R.L. (2005). Meta-Analysis to Assess Impact of Watershed Programme and People's Participation, Comprehensive Assessment Research Report No.8. International Crops Research Institute for the Semi-Arid Tropics (ICRISAT), Patancheru 502 324,Andhra Pradesh, India.

[9] Kolavalli, L. S. and J. Kerr (2002). "Mainstreaming Participatory Watershed Development".Economic and Political Weekly. 37(3): $225-242$. 
[10] MoRD (2006). From Hariyali to Neeranchal: Report of the Technical Committee on watershed Programmes in India, Department of Land Resources, Ministry of Rural Development, Government of India, New Delhi.

[11] Nalatawadmath, S.K, M.S Rama Mohan Rao and M.Padmaiah (1997): 'Joladarasi Model Watershed Development Program in Bellary District of Karnataka-A Diagnostic Evaluation', Journal of Rural Development, Vol 16,No.2 Nalatawadmath, S.K, M.S Rama Mohan Rao and M.Padmaiah (1997): 'Joladarasi Model Watershed Development Program in Bellary District of Karnataka-A Diagnostic Evaluation', Journal of Rural Development, Vol 16,No.2 149

[12] Ninan, K. N. and S. Lakshmikantamma (1994). "Sustainable Development: The Case of Watershed Development in India". International Journal of Sustainable Developmentand World Ecology. 1(4): 229.

[13] Olson Jr. Mancur (1965), The Logic of Collective Action: Public goods and the Theory of Groups, Harvard University Press, Cambridge.

[14] Pingali, P.L.and Rosegrant, M. (2001): Intensive food systems in Asia: Can the degradation problems be resolved? In: Lee, D.R., and Barrett, C.B (eds) Tradeoffs or synergies?Agricultural intensification, economic development and the environment. CABI publishing.

[15] Rao, C.H.H (2000): 'Watershed Development in India - Recent Experience and Emerging Issues,' Economic and Political Weekly, Vol 35, No 45, November 4. Pages 3943-47.

[16] Reddy, V. Ratna (2000). Watershed Development for Sustainable Agricultural: Need for an Institutional Approach, Economic and Political weekly, 35(38): 3435-3444.

[17] Reddy, V. Ratna, et al. (2001). Watershed Development and Livelihood Security: An Assessment of Linkages and Impact in Andhra Pradesh, Project Report, Centre for Economic and Social Studies, Hyderabad.

[18] Reddy. V. Ratna (2002). Water Security and Management: Lessons from South Africa,Economic and Political Weekly. Vol.37 (28): $2827-81$.

[19] Reddy, V. Ratna, M. Gopinath Reddy and John Soussan (2010), Political Economy of Watershed management: Policies, Institutions, Implementation and Livelihoods, Rawat Publishers, Jaipur.

[20] Reddy V. Ratna, M. Gopinath Reddy, S. Galab, John Soussan and Oliver Springate-Briganski (2004), "Participatory Watershed Development in India: Can it Sustain Rural Livelihoods?”, Development and Change, Vol. 35, No. 2, April 2004, pp 297-326.

[21] Reddy, V Ratna; U. Hemantha Kumar; D. Mohan Rao (2005) "Watershed Management for Sustainable Agriculture: Need for An Institutional Approach", Mimeo, CESS,Hyderabad.

[22] Shiferaw, B., V. Ratna Reddy, S. P. Wani., and G.D.N. Rao (2004).Watershed Management and Farmer Conservation Investments in the Semi-Arid Tropics of India : Analysisof Determinants of Resource Use Decisions and Land Productivity Benefits. Socioeconomics and Policy Working Paper Series No. 16. International Crops Research Institute for the Semi-Arid Tropics (ICRISAT), Patancheru 502 324,Andhra Pradesh, India. 150

[23] Singh, Karam et al, (1993): "Kandi Watershed Development Program - A Critical Evaluation", Economic and Political Weekly.

[24] Singh, K., Nirmal Singh, et al. (1995). "Concurrent Evaluation of Watershed Development Project: A Case Study of Punjab". Man and Development. 17(4): 74. 151 